UDK: 005.334: 336.71

POSLOVNA EKONOMIJA BUSINESS ECONOMICS

Godina X

Originalni naučni rad Broj II

Str 66-85

doi: $10.5937 /$ poseko10-13418

PhD Nenad M. Milojević ${ }^{1}$

Mirabank a.d. Beograd

\title{
CONTEMPORARY CHALLENGES IN THE BANKING RISK MANAGEMENT
}

\begin{abstract}
Risk management is one of the crucial parts of today's business banks management. Global economic crisis in the last decade has strongly influence that risk management is having increased importance in the total banking management. Credit risk is still most dominant risk in the banks worldwide. Similar situation is also in the Republic of Serbia. Liquidity, market, operational and other risks are also having increased importance in today's banking. Still, typical dominant risk of average commercial bank is credit risk. High level of non-performing loans is one of the especially important credit risk contemporary challenges. Banks, regulatory bodies and other involved institutions are intensively working on the solutions for this topic. Methods for the risk management are experiencing significant changes and progress in the recent years. Inevitably connected banking topic with previous is capital management progress. In this article current situation in the banking risk management will be analysed. It will be shown in which direction risk management will develop. It will be also analysed actual situation in the banking capital management. Experiences from the Republic of Serbia as well as worldwide banking experiences will be taken into consider. The article will outline recommendations for further risk management progress.
\end{abstract}

${ }^{1}$ nenad.m.milojevic@ gmail.com 
Key words: Banking, Risks, Capital Adequacy.

\section{INTRODUCTION}

Parallel with the processes of globalization, banking business and managing of the bank has becoming compound. The same is valid for the risk management and banking legislation, related to this topic. Global economic crisis in last decade has strongly influence that risk management is having increased importance in the total banking management. Banking capital management is inseparably connected to the risk management. Credit risk is still most dominant risk in the banks worldwide (the same like in Serbia). Other risks are also having increased importance in today's banking, but the domination of the credit risk in the commercial banking is strong.

Central and business banks, regulatory bodies, Basel Committee on Banking Supervision (BCBS) and other involved institutions are intensively working on the solutions for this risk and capital management improvement. Methods for the risk management are experiencing significant changes and progress in the recent years. One of the most important related (credit risk) topics is high level of non-performing loans (NPLs). Banks, regulatory bodies and other involved institutions are intensively working on the solutions for this topic.

During recent period, many researchers worldwide were also analysing banking risk management topics. ${ }^{2}$

The article will outline in which direction is expected that risk management will develop, as well as related capital management. Key starting hypothesis in this paper is following: using local and global experiences in the field of banking risk management and on the basis of viable literature and databases, recommendations for further improvement of the banking risk management, could be made. To draw conclusions it was used experiences from the Republic of Serbia, as well as from global banking. The methodology applied in the paper, is primarily characterized by the following. Historical and the latest domestic and foreign experiences, researches and databases (respecting banking sector of Serbia specifics and Serbian economy), were applied for the risk management analysis. For the previous, especially following methods were relevant: descriptive, inductive - deductive, analytic synthetic and comparative analysis. The most important questions analysed in this paper are following:

\footnotetext{
${ }^{2}$ One of the interesting recent articles: Stulz, R., Risk-Taking and Risk Management by Banks, Journal of Applied Corporate Finance, Volume 27, Issue 1, Winter 2015, Pages 8-18
} 
1. What are the major contemporary challenges in the banking risk management?

2. Could the recommendations for the further banking risk management development, be defined based on recent period experience?

Taking into account conducted analysis the major objectives of the paper are to present comprehensive view on the banking risk management and to provide recommendations for its further development.

\section{CONNECTION BETWEEN CAPITAL AND RISK MANAGEMENT DEVELOPMENT IN THE CONTEMPORERY BANKING}

Connection between capital and risk management development is very strong and dynamic. During previous decades, institutions (BCBS, central and business banks, other regulatory bodies, external credit rating agencies, etc.) which were most involved in defining risk and capital management, were trying to establish adequate balance between risk and capital.

One of the crucial contemporary challenge for the risk and capital management (management of the capital adequacy, etc.), represents the credit risk, for which level, non-performing loans (NPL) have high importance. Situation regarding NPL and CAR worldwide is presented on the Figures 1 and 2.

Figure 1: Ratio of bank non-performing loans (NPL) to total gross loans of the different countries

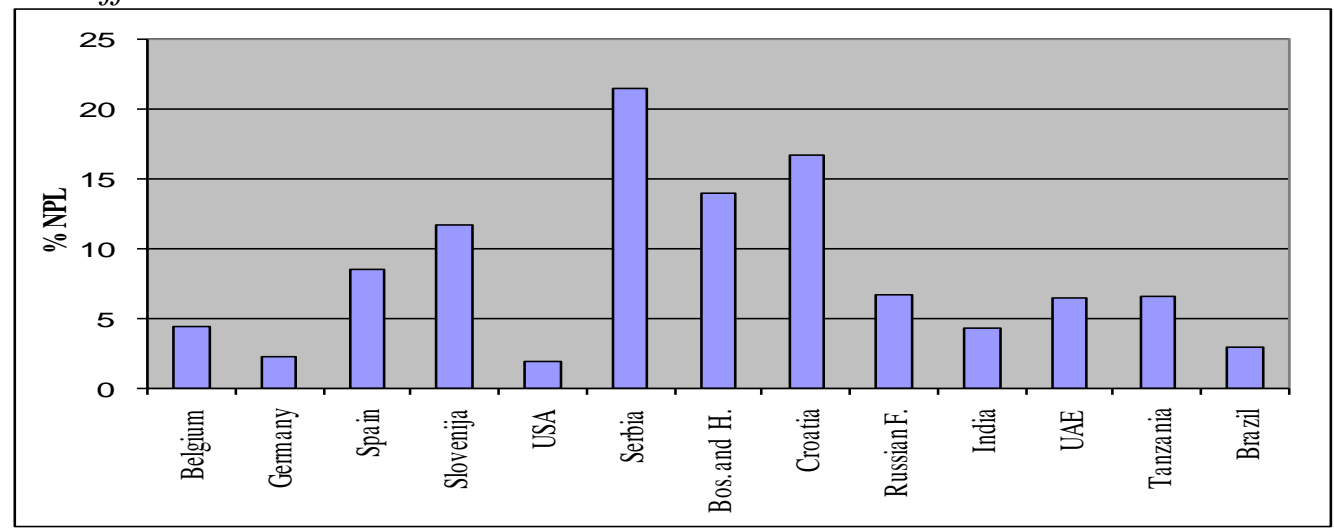

Source: Author, based on the data from: International Monetary Fund, World Development Indicators:

Financial access, stability and efficiency, wdi.worldbank.org/table/5.5\# Note: data as of Q4 2014 
Figure 2: Capital adequacy ratio of the different countries as of second quarter year 2015

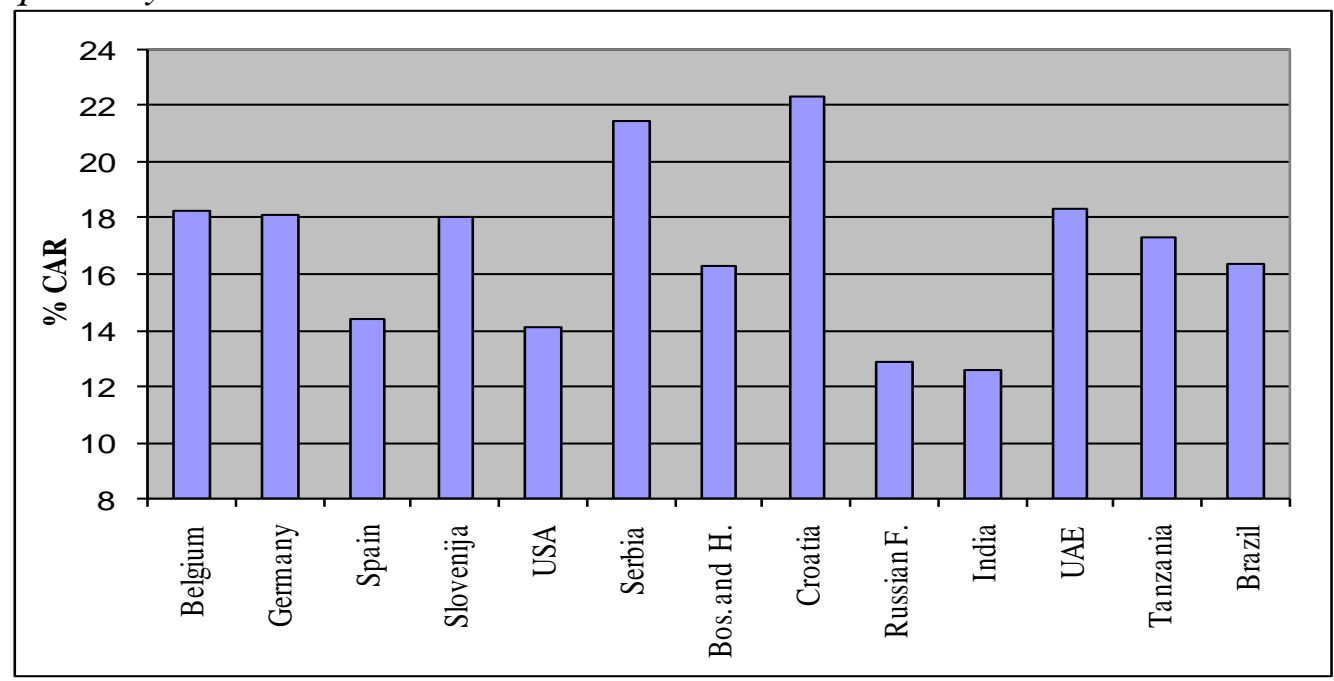

Source: Author, based on the data from: International Monetary Fund, Financial Soundness Indicators http://data.imf.org/?sk=9F855EAE-C765405E-9C9A-A9DC2C1FEE47

BCBS capital standards, in a crucial way are influencing the creation of the banking risk and capital management. During last decades, Basel standards were developing, starting from Basel I, to actual Basel III.

Figure 3: Basel standards development

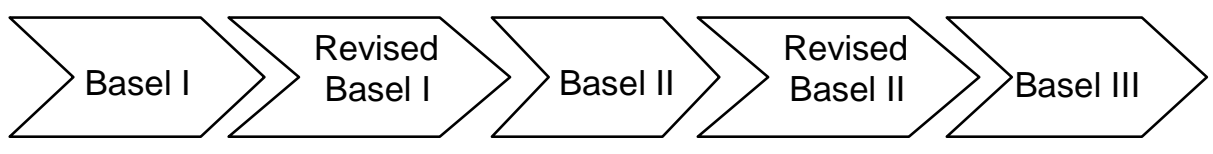

Source: Author

Basel I standard from 1988 (together with its amendments), encountered a wide applications and has manage to contribute to financial stability increase and strengthening of the risk and capital management worldwide. At the beginning this regulatory framework, was focused on the treatment of credit risk and later it took into account the market risk. Basel I was implemented in more than 100 countries and has set the foundation of modern capital and risk management in the world. However, the simplified Basel I regulatory framework has shown some weaknesses. That is the reason why it had to be 
modified and replaced by Basel II, in order to meet the challenges of a new financial era. ${ }^{3}$

With the adoption of Basel II ${ }^{4}$ by the BCBS in 2004 (after which followed a number of amendments in the following years), began a new era in the banking risk and capital management. Basel II regulatory framework represents a step forward in managing banks capital and risk management. Many of the shortcomings of Basel I were resolved: standardized approach (SA) for credit risk measurement has been significantly improved, new, advanced models for the credit risk measurement - internal approach has been offered, operational risk has become relevant for the capital requirement, market risk measurement has been improved, pillar 2 which brings a special qualitative improvement in Basel II compared to Basel have been introduced, and similarly applies to the third pillar.

Based on previous Pillar 1 CAR Basel II calculation is following:

$\frac{\text { Totalregulatorycapital }}{\text { Credit, marketand operationd risk }}=$ Capitaladequacy ratio $\geq 8 \%$

In the Republic of Serbia the CAR regulatory minimum, has long been set at $12 \%$, by the National Bank of Serbia (NBS). Based on this previous formula, in Serbia following CAR calculation is prescribed:

$\frac{\text { Totalregulatorycapital }}{\text { Credit, marketand operationd risk }}=$ Capitaladequacy ratio $\geq 12 \%$

During last period CAR of the Banking sector of Serbia is having average values around $20 \%$ (presented in the table 1), significantly higher than the regulatory minimum of $12 \%$.

3 For more information: Milojević, N., Basel II and Forecasting Implementation Effects, Industrija (Industry), Vol.36, No. 1/2008, 51-65, Economic Institute, Beograd

4 Basel Committee on Banking Supervision, International Convergence of Capital Measurement and Capital Standards - A revised Framework, June 2006 
Table 1: Capital adequacy of the Serbian banking sector (in RSD bln)

\begin{tabular}{|l|r|r|r|r|}
\hline & 31.12 .2012$. & 31.12 .2013$. & 31.12 .2014$. & 30.09 .2015$. \\
\hline TOTAL regulatory capital & $\mathbf{3 5 0 , 1}$ & $\mathbf{3 4 7 , 1}$ & $\mathbf{3 3 9 , 2}$ & $\mathbf{3 5 7 , 3}$ \\
\hline TOTAL capital requirements & $\mathbf{2 1 1 , 4}$ & $\mathbf{1 9 8 , 9}$ & $\mathbf{2 0 4 , 0}$ & $\mathbf{2 0 2 , 0}$ \\
\hline $\begin{array}{l}\text { Credit risk, counterparty risk and } \\
\text { settlement/delivery risk }\end{array}$ & 184,9 & 171,7 & 176,2 & 174,1 \\
\hline Foreign exchange risk & 2,2 & 2,3 & 2,1 & 2,1 \\
\hline Price risk (debt securities) & 0,8 & 1,0 & 1,0 & 0,6 \\
\hline Price risk (equity securities) & 0,0 & 0,0 & 0,0 & 0,0 \\
\hline Operational risk & 23,4 & 24,1 & 24,7 & 25,2 \\
\hline Capital adequacy ratio(\%) & $\mathbf{1 9 , 9}$ & $\mathbf{2 0 , 9}$ & $\mathbf{2 0 , 0}$ & $\mathbf{2 1 , 2}$ \\
\hline
\end{tabular}

Source: Author, based on data from:

National Bank of Serbia - Bank Supervision Department, Banking Sector in Serbia - Third Quarter Report 2015, Beograd, 2015 (statistical annex of the report)

Table 1 is also showing strong domination of credit risk in comparison to all other risks in the Serbian banks. At the end of third quarter of year 2015, $86 \%$ of all capital requirement of the banking sector of Serbia (BSS) is related to the credit risk.

With the adoption of Basel II ${ }^{5}$ by the BCBS in 2004 (after which followed a number of amendments in the following years), began a new era in the banks capital and risk management. Basel II regulatory framework represents a step forward in banks capital and risk management. Many of the shortcomings of Basel I were resolved. However, beside the positive effects on the micro and macro level, such as general improvement in risk and capital management and financial stability, during the recent years some of drawbacks have been manifested. The above-mentioned shortcomings are identified on both micro and macro level. They may also, under certain circumstances negatively impact on the financial stability and economic growth. These phenomena are particularly observed during the global economic crisis. ${ }^{6}$

\footnotetext{
${ }^{5}$ Basel Committee on Banking Supervision, International Convergence of Capital Measurement and Capital Standards - A revised Framework, June 2006

${ }^{6}$ For more information: Milojevic N., Efekti primene Bazelskih standarda u Srbiji, Čugura print i Univerzitet Edukons, Beograd, 2011 and Milojević, N., Perspectives of Banks Capital Requirement Changes Due to the Basel Standards Implementation, Business Economics, Year V, No. 2, Vol. IX, Faculty of Business in Service, Novi Sad, 2011, p. 171-191.
} 


\section{BASEL III STANDARD - CONTEMPORARY RISK AND CAPITAL MANAGEMENT FRAMEWORK}

Negative effects of the global financial crisis have highly prompted creation of the stated Basel III measures and its fast and committed implementation. Additionally one of the major aims of Basel III implementation is to reduce the likelihood of the emergence of new financial crisis and to create conditions for the sustainable economic growth. The global financial crisis highlighted many financial system weaknesses. Some of these weaknesses were following:

- High leverage level, with insufficient banks' high-quality capital;

- Excessive credit growth, fuelled in part by weak underwriting standards and an underestimated credit and liquidity risk;

- Significant systemic risk, interconnectedness among financial institutions and common exposures to similar shocks;

- Inadequate banks capital buffers which could be used for the financial markets procyclicality mitigation and for the maintaining lending to the real economy in times of stress; and

- Insufficient liquidity buffers and excessive exposure to liquidity risk.

BCBS presented revision of the provisions of Basel II in 2009 and 2010. Very soon the provision were called Basel III standard ${ }^{8}$. In the meantime, Basel III standards are updated and implementation has started in EU and other countries. Modifications are very ambitious and challenging for supervisors and commercial banks. Due to the aforementioned, polemics over the application of the new regulatory framework were very intensive. One of the important issues is providing of a significant amount of additional capital for a large number of banks. This is one of the reasons why gradual implementation (Table 2) of certain segments of the new regulatory framework - Basel III is defined for the period of 2013 - 2019 (for some regulatory segments until 2022).

\footnotetext{
7 Basel Committee on Banking Supervision, Finalising post-crisis reforms: an update, November 2015, p. 2.

8 Basel Committee on Banking Supervision, Basel III: A global regulatory framework for more resilient banks and banking systems, June 2011 and Basel Committee on Banking Supervision, Basel III: The Liquidity Coverage Ratio and liquidity risk monitoring tools, January 2013
} 
Table 2: Basel III capital standards phase-in arrangements

\begin{tabular}{|l|c|c|c|c|c|c|c|}
\hline & $\mathbf{2 0 1 3}$ & $\mathbf{2 0 1 4}$ & $\mathbf{2 0 1 5}$ & $\mathbf{2 0 1 6}$ & $\mathbf{2 0 1 7}$ & $\mathbf{2 0 1 8}$ & $\mathbf{2 0 1 9}$ \\
\hline & \multicolumn{2}{|c|}{$\begin{array}{l}\text { Parallel run 1 Jan 2013-1 Jan 2017 } \\
\text { Disclosure starts 1 Jan 2015 }\end{array}$} & & $\begin{array}{c}\text { Migration } \\
\text { to Pillar 1 }\end{array}$ & \\
\hline $\begin{array}{l}\text { Minimum Common Equity Capital } \\
\text { Ratio (CET1) }\end{array}$ & $3.5 \%$ & $4.0 \%$ & $4.5 \%$ & $4.5 \%$ & $4.5 \%$ & $4.5 \%$ & $4.5 \%$ \\
\hline Capital conservation buffer & & & & $0.625 \%$ & $1.25 \%$ & 1.875 & $2.5 \%$ \\
\hline $\begin{array}{l}\text { Minimum common equity plus } \\
\text { capital conservation buffer }\end{array}$ & $3.5 \%$ & $4.0 \%$ & $4.5 \%$ & 5.125 & $5.75 \%$ & 6.375 & $7.0 \%$ \\
\hline $\begin{array}{l}\text { Phase-in of deductions from CET1 } \\
\text { Minimum Tier 1 Capital }\end{array}$ & $4.5 \%$ & $5.5 \%$ & $6.0 \%$ & $6.0 \%$ & $6.0 \%$ & $6.0 \%$ & $6.0 \%$ \\
\hline $\begin{array}{l}\text { Minimum Total Capital } \\
\text { Minimum Total Capital plus } \\
\text { conservation buffer }\end{array}$ & $8.0 \%$ & $8.0 \%$ & $8.0 \%$ & $8.0 \%$ & $8.0 \%$ & $8.0 \%$ & $8.0 \%$ \\
\hline $\begin{array}{l}\text { Capital instruments that no longer } \\
\text { qualify as } \\
\text { non-core Tier 1 capital or Tier 2 } \\
\text { capital }\end{array}$ & $8.0 \%$ & $8.0 \%$ & $8.0 \%$ & 8.625 & $9.25 \%$ & 9.875 & $10.5 \%$ \\
\hline
\end{tabular}

Source: Author, based on data from:

Basel Committee on Banking Supervision, Basel III: A global regulatory framework for more resilient banks and banking systems, June 2011, p. 77.

Similar to previous Basel standards, Basel III standard is (or will be) implemented very massively worldwide. In the year 2015, Basel III rules were implemented or are in process of implementation in 122 countries. $^{9}$

Basel III puts emphasis on banking capital strengthening (especially in enhancing the quality of capital), as well as the treatment of the taken risks. Also the liquidity risk and liquidity management is getting considerably more attention. During the period of the 2013 - 2019, according to the actual plan, among others, the following is gradually becoming effective: leverage ratio, capital buffer, higher capital ratios minimum allowable levels and new liquidity ratios.

Leverage ratio is (again) used by the Basel III, as a additional indicator for the capital and risk management. Actually, leverage ratio has been used in the banking long time ago, but during last two decades it was eclipsed by the more sophisticated Basel capital standards. Now, with Basel III, Leverage ratio is again receiving full attention by the capital and risk managers. A non-riskbased leverage ratio that includes off-balance sheet exposures will serve as a backstop to the risk-based capital requirement. Also helps contain system wide build up of leverage.

9 Basel Committee on Banking Supervision, Implementation of Basel standards - A report to G20 Leaders on implementation of the Basel III regulatory reforms, November 2015, p. 7. 
Work on countercyclical measures, macro prudential measures and other measures for strengthening financial stability are very intensive as well as cooperation with other relevant institutions regarding the opportunities for innovation provisioning segment. Basel III macro prudential overlay that includes capital buffers (and many additional indicators, measures, tool, etc.) is one of the important improvements in comparison to the Basel II.

Basel III is also focused on the systemically important financial institutions (SIFIs). In addition to meeting the Basel III requirements, SIFIs must have higher loss absorbency capacity to reflect the greater risks that they pose to the financial system. This legislation is introduced in the Basel III, based on one of the lessons from the global financial crisis, related to the situation with the SIFIs during the crisis and huge amounts of capital injections necessary for their recovery.

Basel III is improving Liquidity risk treatment. The two crucial new ratios are: Net stable funding ratio (NSFR) and Liquidity coverage ratio (LCR).

NSFR is a longer-term structural ratio designed to address liquidity mismatches. It covers the entire balance sheet and provides incentives for banks to use stable sources of funding.

$\frac{\text { Available amount of stable funding }}{\text { Required amount of stable funding }}>100 \%$

The second ratio - LCR is requiring from banks to have sufficient highquality liquid assets to withstand a 30 -day stressed funding scenario that is specified by supervisors.

$\frac{\text { High - quality liquid assets }}{\text { Totalnet cash outflows over thenext } 30 \text { calendar days }} \geq 100 \%$

One of the König ${ }^{10}$ recent analysis, is highlighting that implementation of the new liquidity risk management tools should be carefully performed, with the aim to avoid potential negative effects.

Regarding Pillar 2 requirements, Basel III is introducing improved risk management and supervision, like following:

- Address firm-wide governance and risk management;

- Capturing the risk of off-balance sheet exposures and securitisation activities;

10 König, P. J., Liquidity Requirements: A Double-Edged Sword, International Journal of Central Banking, Volume 11, Number 4 December 2015, Pages 129-168, Economic Research Department, Federal Reserve Bank of San Francisco 
- Managing risk concentrations;

- Providing incentives for banks to better manage risk and returns over the long term;

- Sound compensation practices;

- Valuation practices;

- Stress testing;

- Accounting standards for financial instruments;

- Corporate governance and

- Supervisory colleges. ${ }^{11}$

It should be also mentioned that strengthened disclosures requirements and market discipline are one of the goals of the Basel III revised Pillar 3.

Although, the Basel III is giving significant results and improvements, it is necessary to continue with further changes and provisions improvement.

\section{RISK MANAGEMENT PERSPECTIVES - ACTIVITIES OF THE INVOLVED INSTITUTIONS}

In the previous parts of the paper, institutions (BCBS, central banks and other regulatory bodies, business banks, external credit rating agencies, etc) which activities are crucial for the banking management (especially risk management) shaping are mentioned. The role of the BCBS, in the risk management development, has been analysed in stated segments. Regarding risk management perspectives, following should be highlighted.

Banking legislation institutions (including Central banks) of the Europe and all other continents are very active in the implementation of Basel III standard and other related standards for the risk and capital management. Similar situation is in Serbia, where NBS investing lot of efforts to follow and implement actual European banking regulatory trends. It can be expected that in near future Basel III standard will be fully implemented in Serbia. Actual CAR regulation in the Serbia is mostly based on Basel II legislation, but with some local specifics. Serbian central bank has already implemented some Basel III elements in the local legislation. In the year 2015, NBS and commercial banks have conducted quantitative study regarding Basel III capital and liquidity risk standards implementation. NBS has also achieved lot of results in other actual banking legislation pillars implementation. It should be mentioned, that lot of sophisticated risk management methods are already part of the banking management of the banks in Serbia. Some of these methods are implemented, based on NBS regulation and some of them in cooperation

11 Basel Committee on Banking Supervision, Basel III overview table: Basel Committee on Banking Supervision reforms - Basel III,

https://www.bis.org/bcbs/basel3/b3summarytable.pdf 
with mother banks of Serbian bank, or based on the initiative of Serbian banks themselves.

One more institution, which has very important role for risk management perspectives, is the Financial Stability Board (FSB). This institution is very active in the field of global financial system strengthening and development of the banking risk management. Total Loss Absorbing Capacity (TLAC) indicator is one of the bank management tools, develop for this purpose. The minimum Pillar 1 TLAC requirement is a requirement for loss absorbing capacity on both a going concern and gone concern basis, incorporating existing Basel III minimum capital requirements and excluding Basel III capital buffers. The stated bank management tool is integrating both risk and capital management. The TLAC requirement should ensure adequate availability of loss-absorbing capacity in resolution. The aim is to establish a framework that is consistent with the Basel capital framework and continues to set appropriate incentives for firms to be well capitalised. The kinds of instruments that count towards satisfying existing minimum regulatory capital requirements would therefore also count towards satisfying the common minimum Pillar 1 TLAC requirement. TLAC is set within the range of $16-$ $20 \%$ of risk-weighted assets (RWA), and at a minimum twice the Basel III leverage requirement. ${ }^{12}$ TLAC development has induce further banking risk management development, worldview.

In the connection with previous, EU regulatory bodies are very active on the closely related topics of the Bank Recovery and Resolution Directive (BRRD). In the Republic of Serbia and other countries, similar activities can be seen. The financial crisis has shown need for the development of the tools to deal effectively with unsound or failing credit institutions and investment firms. Such tools are needed, in particular, to prevent insolvency or, when insolvency occurs, to minimise negative repercussions by preserving the systemically important functions of the institution concerned. During the crisis, those challenges were a major factor that forced EU states to save institutions using taxpayers' money. The objective of a credible recovery and resolution framework is to obviate the need for such action to the greatest extent possible. 13

Related to stated BRRD activities, EU has developed new banking management indicator, which is taking into consider the calculation of the Minimum Required Eligible Liabilities (MREL). Very soon, this indicator has started to be used (in some form) in other countries (outside the EU). MREL requirement is expressed as percentage of total liabilities (including capital).

12 Financial Stability Board, Adequacy of loss-absorbing capacity of global systemically important banks in resolution - Consultative Document, November 2014, p. 1-7.

13 The European Parliament and the Council of the European Union, Directive 2014/59/EU of the European Parliament and of the Council, Official Journal of the European Union, p. 1. 
Requirement is set on the case-by-case bases, for each credit institution. During previous period NBS was very active in the involving of the BRRD standards and MREL in the Serbian banking regulation. ${ }^{14}$ Especially during year 2015, NBS and business banks in Serbia were very active on this field. In 2016, these activities are continuing and further progress on this important segment of the banking management, should be expected.

Activities of the External credit rating agencies had also high importance for the banking management, during previous period. It seems that this will be also situation in the future period, although some activities are (again) going into direction of increasing importance of the internal ratings (conducted within business banks). The credit rating development in recent years is linked to the development of the global risk and capital management system of the banks. Presenting a measure of credit risk, or the assessment of a debtor ability to repay the loan or to pay its other obligations, credit rating, has become an unavoidable element of the credit risk assessment. In recent decades, parallel with the growth of the importance of credit ratings, in the global financial system there is a strengthening of the role of agencies involved in credit rating assessment.

With the advent of the global financial crisis, there is a significant decrease in credit ratings level of many entities: the states, banks, companies, etc. Additionally, it was obvious that the revision of credit ratings and its function in the worldwide financial sector is necessary. Mentioned reform has been conducted during the last few years. Reform is important for both, the credit ratings assigned by external rating agencies, but also for the internal ratings, such as those developed by financial institutions, for the rating of its debtors. The aim of the reform of both rating segments is improvement of ratings as instrument for credit risk level determining. Additionally, reform should enable that reliance of the participants in the financial system on the credit ratings does not lead to fostering / generating economic crisis. Republic Serbia in recent years, aims to rapidly modernize the financial system and to achieve further integration into global financial flows. Inevitably with this process, the importance of credit ratings is increasing, as well as the need for development of internal and external rating processes in the Serbia.

Although Basel III standard is still not fully implemented, analysis about Basel III update or new Basel capital and risk standards (by the experts called Basel IV) are very intensive. Among other things, Basel III update or Basel IV

14 Decision on the Minimum Requirement for Capital and Eligible Liabilities of a Bank, RS Official Gazette, No 30/2015;

Decision on Information and Data to be Submitted to the National Bank of Serbia for the Purpose of Drawing up and Updating the Resolution Plan for Bank and Banking Group, RS Official Gazette, No 78/2015;

Decision on Recovery Plans of Banks and Banking Groups, RS Official Gazette, No 71/2015. 
should also bring changed role of the external credit rating in the CAR calculation. The idea is that the credit risk weighted assets (RWA) calculation, will not strongly depend on the external credit ratings.

Regarding CAR calculation, Basel III, was more focused on the capital: components, quality, quantity and requirements. On the other side, Basel IV is mainly focused on the risks and risk management, aiming to redefine the RWA calculation. Credit, market and operational risk will be redefined. Risk weights for the credit risk standardised approach will be much wider and risk sensitive. For example risk weights for the corporates of $60-300 \%$ is much higher than the current range of $20-150 \%$; risk weights for the exposure to other banks starts at 30\%, rather than the current 20\%, etc. Expectations from the Basel IV risk management evolution are high and this could mean start of the new chapter in the risk management development.

Banks which are using internal models may be constrained by the proposal for a capital floor used on the new standardised approach. Basel IV implementation will be definitely demanding for the banks (IT systems, risk modules, strategies, policies, business plans, etc.). Planned quantitative studies, should show if Basel IV can produce higher lending costs and in which amount. This could have significant impact not only on the total bank management, but also on the economy, so the implementation should be carefully planned.

In the previous part of article, it has been mentioned that credit risk is still representing crucial risk in the worldwide banking (and the same situation is in Serbia). One of the crucial challenges for the credit risk management represents the NPLs level.

Table 3: Non-performing loans of the Banking sector of Serbia (gross NPL indicator)

\begin{tabular}{|l|r|r|r|r|r|}
\hline & 31.12 .2011$. & 31.12 .2012$. & 31.12 .2013$. & 31.12 .2014$. & 30.09 .2015$. \\
\hline TOTAL Non-performing loans \% & $19,0 \%$ & $18,6 \%$ & $21,4 \%$ & $21,5 \%$ & $22,0 \%$ \\
\hline TOTAL Non-performing loans RSD bln. & 342,7 & 365,8 & 395,3 & 421,3 & 425,0 \\
\hline
\end{tabular}

Source: Author, based on data from:

National Bank of Serbia - Bank Supervision Department, Banking Sector in Serbia - Third Quarter Report 2015, Beograd, 2015 (statistical annex of the report)

High NPL level is present in the BSS. High level of the NPLs is one of the major problems of the BSS. Commercial banks are together with the NBS intensively looking for the solution, to reduce the NPLs, which share in the total loans is more than $20 \%$ (previous table). Opinions of the various international institutions have been taken into account, as well as global and Serbian experience regarding this topic. Among other thing action plans for 
solving of the NPLs has been defined by the NBS, but also by the Government of the Republic of Serbia. ${ }^{15}$ Similar actions have been conducted by the business banks. Currently, this topic, occupies full attention of all involved parties and lot of actions are ongoing (NPL market development, law solutions, extrajudicial solutions, etc.). Definitely, NPL topic will continue to requires full attention of all involved parties, so that the adequate solutions would be performed.

Table 4: Classified assets of the Banking sector of Serbia

\begin{tabular}{|c|c|c|c|c|c|c|c|c|c|c|}
\hline & \multicolumn{2}{|c|}{31.12 .2012}$. & \multicolumn{2}{|c|}{ 31.12.2013. } & \multicolumn{2}{|c|}{ 31.03.2014. } & \multicolumn{2}{|c|}{31.12 .2014}$. & \multicolumn{2}{|c|}{ 30.09.2015. } \\
\hline $\begin{array}{l}\text { Balanc } \\
\text { e sheet } \\
\text { assets }\end{array}$ & $\begin{array}{c}\text { RSD } \\
\text { bln }\end{array}$ & $\%$ & $\begin{array}{c}\text { RSD } \\
\text { bln }\end{array}$ & $\%$ & $\begin{array}{l}\text { RSD } \\
\text { bln }\end{array}$ & $\%$ & $\begin{array}{c}\text { RSD } \\
\text { bln }\end{array}$ & $\%$ & $\begin{array}{c}\text { RSD } \\
\text { bln }\end{array}$ & $\%$ \\
\hline A & $1.051,6$ & 49,6 & 991,1 & 49,7 & $1.010,4$ & 51,3 & $1.148,8$ & 52,7 & $1.083,9$ & 51,0 \\
\hline B & 419,9 & 19,8 & 332,9 & 16,7 & 306,9 & 15,6 & 378,9 & 17,4 & 376,5 & 17,7 \\
\hline $\mathrm{C}$ & 178,7 & 8,4 & 174,3 & 8,7 & 148,9 & 7,6 & 144,0 & 6,6 & 164,3 & 7,7 \\
\hline $\mathrm{D}$ & 88,2 & 4,2 & 112,6 & 5,6 & 101,5 & 5,2 & 80,0 & 3,7 & 63,3 & 3,0 \\
\hline$E$ & 379,8 & 17,9 & 383,4 & 19,2 & 402,3 & 20,4 & 429,2 & 19,7 & 437,8 & 20,6 \\
\hline Total & $2.118,2$ & 100,0 & $1.994,3$ & 100,0 & $1.970,0$ & 100,0 & $2.180,8$ & 100,0 & $2.125,8$ & 100,0 \\
\hline $\begin{array}{l}D \text { and } \\
E \text { (as } \\
\% \text { of } \\
\text { total } \\
\text { assets) }\end{array}$ & & 22,1 & & 24,9 & & 25,6 & & 23,3 & & 23,6 \\
\hline
\end{tabular}

Source: Author, based on data from:

National Bank of Serbia - Bank Supervision Department, Banking Sector in Serbia - Third Quarter Report 2015, Beograd, 2015 (statistical annex of the report)

On the table 4 , it is presented similar information regarding quality of the Serbian banking assets, like it was presented on the NPL table 3. Share of the bad quality assets is still high. Assets of the lowest quality: "D" and "E", has share of 23,6\% in the total assets at the end of Q3 2015.

Stress tests are also having increased importance for the banking risk management in the last decades. Expectations from them are also high. Basel II has representing a big step in the banking stress test development. Similar trend has continued with the Basel III. Additionally stress tests related to the Asset quality review (AQR) has given new quality to the global and individual banking management. European Central Bank (ECB) has put big attention to this issue, while other central banks were following their example (similar was in Serbia). Reclassification of the credit exposures from performing to

15 For further information: Government of Republic of Serbia, NPL Resolution Strategy, http://www.mfin.gov.rs/UserFiles/File/strategija\%20krediti/2\%20NPL\%20Strategija\%20\%2 8eng\%29.pdf 
non-performing, as well as demand for the increased provisioning, was representing very significant challenge for the European banks. Stress tests and asset analysis will continue to have substantial function as a tool of regulators, for the capital and risk strengthening in banks, as well financial stability strengthening instrument. It is expected increased importance of the AQR in developed, as well as in developing countries.

Commercial banks worldwide have demanding task to follow all various instructions regarding risk management improvement. Based on their practical experience with the negative effects of the financial crisis, banks are additionally improving their processes and practise, as well as strategies, planning, policies, procedures, etc. In the same time, among other challenges banks are also trying to cope with: high risks and high capital requirements, solving of the high level of NPLs and keeping sustainable business, which should provide long term stability of the bank. Similar challenges (high NPL level, low profitability, fragile economy, etc) are present in the banking sector of Serbia.

Besides already mentioned methods for the implementation provided by the various supervisory institutions, banks are trying to develop additionally their own improved tools and systems for the risk management, like for example: clients risk assessment tools and various risk assessment and measuring tools. Banks are also trying to find adequate measure for their business, between strategies like: change the risk profile of the bank, reduced the risk and business or increase it, recapitalization, etc.

\section{CONCLUDING REMARKS}

The paper has outlined the major characteristics of the banking risk management, which is one of the most crucial parts of today's business banks management. In the article it is presented development, experiences and perspectives, which are relevant for the banking risks.

Credit risk is still most dominant risk in the banks worldwide. Similar situation is also in the Republic of Serbia. Liquidity, market, operational and other risks are also having increasing importance in today's banking. Still, typical dominant risk of average commercial bank is credit risk. At the end of third quarter of year 2015, 86\% of all capital requirements of the BSS is related to the credit risk. During previous years, similar domination of credit risk in the Serbia and other countries has been seen.

High level of non-performing loans is one of the especially important credit risk topics. Banks, regulatory institutions worldwide and other involved parties are intensively working on the solutions for this topic. High level of the NPLs is one of the major problems of the BSS. Commercial banks are together 
with the NBS intensively looking for the solution, to reduce the NPLs, which share in the total loans is more than $20 \%$. For the solving of this issue, among other things, action plans for solving of the NPLs has been defined by the NBS, but also by the Government of the Republic of Serbia. Similar actions have been conducted by the business banks. Currently, this topic, occupies full attention of all involved parties and lot of actions are ongoing (NPL market development, law solutions, extrajudicial solutions, etc.). Definitely, NPL topic will continue to requires, full attention of all involved parties, so that the adequate solutions would be performed.

Methods for the risk management are experiencing significant changes and progress in the recent years. Inevitably connected banking topic with previous is capital management progress. Banking legislation institutions (including Central banks) of the Europe and all other continents are very active in the implementation of Basel III standard and other related standards for the risk and capital management. Similar situation is in Serbia, where NBS investing lot of efforts to follow and implement actual European banking regulatory trends. Actual CAR regulation in the Serbia is mostly based on Basel II legislation, but with some local specifics. Serbian central bank has already implemented some Basel III elements in the local legislation. During last period CAR of the Banking sector of Serbia is having average values around $20 \%$, significantly higher than the regulatory minimum of $12 \%$.

Although Basel III standard is still not fully implemented, analysis about Basel III update or new Basel capital and risk standards (by the experts called Basel IV) are very intensive. Among other things, Basel III update or Basel IV should also bring changed role of the external credit rating in the CAR calculation. The idea is that the credit RWA calculation will not strongly depend on the external credit ratings. Basel IV is mainly focused on the risks and risk management, aiming to redefine the RWA calculation.

Processes like changed role of the external and internal credit ratings, stress tests and AQRs, Bank Recovery and Resolution activities and other similar process are also having increased importance for the banking management. EU has started first with Bank Recovery and Resolution activities development, followed by the other countries, including Republic of Serbia. Bank Recovery and Resolution activities are bringing many new, important and demanding indicators (TLAC, MREL, etc).

Based on commercial banks practical experience with the negative effects of the financial crisis they are additionally improving their processes and practise, as well as strategies, planning, policies, procedures, etc. In the same time, among other challenges banks are also trying to cope with: high risks, high level of NPLs and keeping sustainable business, which should provide long term stability of the bank. Business banks are trying to develop additionally their own improved tools and systems for the risk management. In 
the paper outlined ongoing process of the banking risk management development, is expected to continue. This should be also valid for the banks in Serbia.

\section{REZIME SAVREMENI IZAZOVI U UPRAVLJANJU RIZICIMA BANAKA}

Upravljanje rizicima je jedan od ključnih elemenata bankarskog menadžmenta. Tokom poslednjih decenija, svetska ekonomska kriza je snažno uticala, da upravljanje rizicima, dobije još više na značaju, u okviru ukupnog upravljanja poslovnim bankama. Kreditni rizika je i dalje dominantan rizik u svetskom bankarsku, a slična situacija je i Republici Srbiji. Rizik likvidnosti, tržišni, operativni i drugi rizici, takođe sve više dobijaju na značaju, u svetskom bankarstvu. Ipak, kreditni rizik je dalje najvažniji rizik prosečne poslovne banke. Visok nivo problematičnih kredita je jedan od posebno bitnih savremenih izazova, povezanih sa kreditnim rizikom. U bankarskom sektoru Srbije, nivo problematičnih kredita, već duže vremena prelazi $20 \%$ ukupnih kredita. Ovako visok nivo problematičnih kredita, uslovio je intenzivan rad, brojnih institucija u zemlji, kako bi ovaj problem bio rešen u što kraćem roku. Veoma pozitivan element, predstavljam dobra kapitalizovanost bankarskog sektora Srbije. Naime, pokazatelj adekvatnosti kapitala (PAK), bankarskog sektora Srbije (BSS), već duže vremena se kreće oko 20\%, što je znatno iznad regulatornog minimuma od $12 \%$. Ovako visok nivo PAK, povećava manevarski prostor u borbi sa izazovima i rizicima. Poslovne banke, regulatorna tela i druge relevantne institucije, intenzivno rade na svim aspektima upravljanja rizicima. Metodi upravljanja rizicima, doživljavaju značajne promene i razvoj poslednjih godina. Razvoj upravljanja kapitalom, predstavlja direktno povezanu temu, sa razvojem upravljanja rizicima. U ovom radu je analizirana trenutna situacija u upravljanju rizicima banaka. Predstavljeno je na koji način se očekuje da će se upravljanje rizicima razvijati $\mathrm{u}$ narednom periodu. Aktuelna situacija u oblasti upravljanja kapitalom banaka, je takođe analizirana. Ključna polazna hipoteza u radu je sledeća: koristeći domaća i svetska iskustva u oblasti upravljanja rizicima banaka, a na osnovu raspoložive literature i baza podataka, moguće je dati preporuke za dalje unapređenje upravljanja rizicima banaka. Za izvođenje zaključaka, korišćena su iskustava iz Republike Srbije, kao i svetskog bankarstva. Metodologija koja je u radu primenjena, prvenstveno karakteriše sledeće. Korišćena su istorijska i najsavremenija svetska i domaća iskustva, istraživanja i baze podatka (uz uvažavanje specifičnosti BSS i ekonomije Srbije), za sagledavanje i analizu upravljanja rizicima. Analizirani su i upoređeni brojni načini i segmenti upravljanja rizicima. Za prethodno, posebno su sledeće 
metode bile relevantne: deskriptivna, induktivno - deduktivna, analitičko sintetička i komparativna analiza. Uvažavajući sprovedene analize, u radu su date preporuke za dalji razvoj upravljanja rizicima banaka.

Ključne reči: bankarstvo, rizici, adekvatnost kapitala.

\section{REFERENCES}

1. Alexander, C. and Sheedy, E., The Professional Risk Managers' Handbook: A Comprehensive Guide to Current Theory and Best Practices, PRMIA Publications, Wilmington, 2004

2. Basel Committee on Banking Supervision, Basel III overview table: Basel Committee on Banking Supervision reforms - Basel III, https://www.bis.org/bcbs/basel3/b3summarytable.pdf

3. Basel Committee on Banking Supervision, Basel III: A global regulatory framework for more resilient banks and banking systems, June 2011

4. Basel Committee on Banking Supervision, Basel III: The Liquidity Coverage Ratio and liquidity risk monitoring tools, January 2013

5. Basel Committee on Banking Supervision, Finalising post-crisis reforms: an update, November 2015

6. Basel Committee on Banking Supervision, Implementation of Basel standards - A report to G20 Leaders on implementation of the Basel III regulatory reforms, November 2015

7. Basel Committee on Banking Supervision, International Convergence of Capital Measurement and Capital Standards, July 1988, updated to April 1998

8. Basel Committee on Banking Supervision, International Convergence of Capital Measurement and Capital Standards - A revised Framework, June 2006

9. Catarineu-Rabell, E., Jackson, P., Tsomocos, D.P., Procyclicality and the new Basel Accord - Banks' Choice of Loan Rating System, Bank of England, Working Paper no. 181, London, 2003

10. Cecchetti S. G, and Kharroubi, E., Reassessing the Impact of Finance on Growth, Bank for International Settlements, BIS Working Papers No. 381, 2012

11. Decision on Capital Adequacy of Banks, RS Official Gazette, No 46/2011, $6 / 2013$ and $51 / 2014$

12. Decision on Information and Data to be Submitted to the National Bank of Serbia for the Purpose of Drawing up and Updating the Resolution Plan for Bank and Banking Group, RS Official Gazette, No 78/2015 
13. Decision on Recovery Plans of Banks and Banking Groups, RS Official Gazette, No 71/2015

14. Decision on the Minimum Requirement for Capital and Eligible Liabilities of a Bank, RS Official Gazette, No 30/2015

15. Financial Stability Board, Adequacy of loss-absorbing capacity of global systemically important banks in resolution - Consultative Document, November 2014

16. Fitch Ratings, http://www.fitchratings.com/

17. Government of Republic of Serbia, NPL Resolution Strategy, http://www.mfin.gov.rs/UserFiles/File/strategija\%20krediti/2\%20NPL\%2 0Strategija\%20\%28eng\%29.pdf

18. International Monetary Fund, Financial Soundness Indicators, http://data.imf.org/?sk=9F855EAE-C765-405E-9C9A-A9DC2C1FEE47

19. International Monetary Fund, World Development Indicators: Financial access, stability and efficiency, wdi.worldbank.org/table/5.5\#

20. Kashyap K., and Stein, J., Cyclical implications of the Basel II capital standards, Federal Reserve Bank of Chicago, Economic Perspectives, $1 \mathrm{Q} / 2004$.

21.König, P. J., Liquidity Requirements: A Double-Edged Sword, International Journal of Central Banking, Volume 11, Number 4 December 2015, Pages 129-168, Economic Research Department, Federal Reserve Bank of San Francisco

22. Masschelein, N., Monitoring pro-cyclicality under the capital requirements directive: preliminary concepts for developing a framework, National Bank of Belgium, Working Paper No. 120 - October 2007.

23. Milojevic N., Efekti primene Bazelskih standarda u Srbiji, Čugura print i Univerzitet Edukons, Beograd, 2011.

24. Milojević, N., Basel II and Forecasting Implementation Effects, Industrija (Industry), Vol.36, No. 1/2008, 51-65, Economic Institute, Beograd

25. Milojević, N., Perspectives of Banks Capital Requirement Changes Due to the Basel Standards Implementation, Business Economics, Year V, No. 2, Vol. IX, Faculty of Business in Service, Novi Sad, 2011, p. 171-191

26. Moody's Investors Service, http://www.moodys.com/

27. National Bank of Serbia - Bank Supervision Department, Banking Sector in Serbia - Third Quarter Report 2015, Beograd

28. National Bank of Serbia, http://www.nbs.rs

29. Standard \& Poor's Ratings Services, http://www.standardandpoors.com/

30. Stulz, R., Risk-Taking and Risk Management by Banks, Journal of Applied Corporate Finance, Volume 27, Issue 1, Winter 2015, Pages 8-18, WileyBlackwell 
31. The European Parliament and the Council of the European Union, Directive 2014/59/EU of the European Parliament and of the Council, Official Journal of the European Union

Ovaj rad je primljen 26.01.2016., a na sastanku redakcije časopisa prihvćen za štampu 15.03.2017. godine. 